\title{
Glyphosate resistance of Eleusine indica populations from North Sumatra, Indonesia
}

\author{
KOKO TAMPUBOLON ${ }^{1}$, EDISON PURBA ${ }^{2, \bullet}$, MOHAMMAD BASYUNI ${ }^{3}$, DIANA SOFIA HANAFIAH ${ }^{2}$ \\ ${ }^{1}$ Doctoral Program of Agricultural Science, Faculty of Agriculture, Universitas Sumatera Utara. Jl. Prof. A. Sofyan No.3, Padang Bulan, 20155, \\ Indonesia \\ ${ }^{2}$ Program of Agrotechnology, Faculty of Agriculture, Universitas Sumatera Utara. Jl. Prof. A. Sofyan No.3, Padang Bulan, 20155, Indonesia. \\ Tel.: +62-61-8213236, `email: epurba@yahoo.com, kokotampubolon@gmail.com \\ ${ }^{3}$ Department of Forestry, Faculty of Forestry, Universitas Sumatera Utara. Jl. Tri Darma Ujung No.1, Padang Bulan, Medan 20155, Indonesia
}

Manuscript received: 13 April 2019. Revision accepted: 21 June 2019.

\begin{abstract}
Tampubolon K, Purba E, Basyuni M, Hanafiah DS. 2019. Glyphosate resistance of Eleusine indica populations from North Sumatra, Indonesia. Biodiversitas 20: 1910-1916. Controlling of Eleusine indica populations in oil palm plantations using a similar mode of action of herbicide may cause resistant weed. Overall E. indica populations from oil palm plantations in North Sumatra, Indonesia have never been reported to be glyphosate-resistant. This research was aimed to determine the survival percentage and to classify the resistance of E. indica to glyphosate from oil palm plantations in 11 districts in North Sumatra Province. The research was conducted in the Weed Research Center Field Laboratory, Faculty of Agriculture, Universitas Sumatera Utara from October 2016 to August 2017. This research was arranged in a Randomized Block Design with the glyphosate-treatment using a recommended dose of two $1 \mathrm{ha}^{-1}$ and three replications. The ESU population was collected in the soccer field of Politeknik Negeri Medan (Medan city) was used as a check, and has never been exposed to the herbicide. Parameters were analyzed using one-way ANOVA, and the means were compared using DMRT at a probability level of 5\%. The results showed that $276(65.56 \%)$ of 421 populations were classified as glyphosate-resistant, 88 populations $(20.90 \%)$ were classified as glyphosate-resistant developing, and 57 populations (13.54\%) were classified as glyphosate-susceptible. The highest range of dry weight of glyphosate-resistant $E$. indica populations were found in 5 districts including South Labuhanbatu District followed by the Serdang Bedagai, Simalungun, Asahan, and North Labuhanbatu Districts. The observed resistance level and dry weight range in the present study indicated the failure in controlling $E$. indica due to continued use of glyphosate and the potency of $E$. indica distribution into other oil palm estates due to its high biomass production capability.
\end{abstract}

Keywords: Eleusine indica, glyphosate, North Sumatra, oil palm plantations, resistance

\section{INTRODUCTION}

Eleusine indica is a fast growing plant under high sunlight intensity and classified as $\mathrm{C}_{4}$ plant (AmpongNyarko and De Datta 1992). E. indica has 2 sets of chromosomes (diploid), self-pollinated, annual weeds, and its genome size is relatively small approximately $8.03 \times 10^{8}$ bp (Ganeshaiah and Umashaanker 1982; Mysore and Baird 1997). This weed can produce up to 140,000 seeds plant ${ }^{-1}$ (Chin 1979). The high sunlight intensity condition at oil palm plantations in Indonesia during the pre-and mainnursery to the immature plant (IP) enables $E$. indica has a more rapid growth as compared to the mature plant (MP). Based on field observations, $E$. indica needs only two months to grow and develop from germination to the generative phase. E. indica populations on oil palm nursery, both in the pre-and main-nursery until immature plant (IP) is more dominant than a mature plant (MP), which in turn reduces plant production. In general, weed control in oil palm plantations is carried out using herbicide once in 3-4 months. Glyphosate is one of the most often used herbicides for controlling weeds in oil palm plantations.

Glyphosate, $N$-(phosphonomethyl) glycine, is a derivative of glycine amino acids and phosphonic acid.
Glyphosate is generally formulated as salt in soluble water and is a non-selective herbicide which can control various types of annual and perennial weeds. Glyphosate inhibits the enzyme 5-enolpyruvylshikimate-3-phosphate synthase (EPSPS) in the plant chloroplast tissue which converts shikimate-3-phosphate (S-3-P) into enolpyruvylshikimate3-phosphate (EPSP) leading to the production of amino acids, phenylalanine, tyrosine, and tryptophan (Monaco et al. 2002). The repeated use of herbicides with similar active ingredients for long periods can cause weeds to become more difficult to control (Purba 2009). According to Knezevic et al. (2017), herbicide-resistant weeds are the weed species that have the ability to develop and keep surviving after being exposed to herbicides. The use of the same herbicides intensively and continuously over the past few decades may have resulted in the evolution of herbicide-resistant weeds. These evolutionary event is usually caused by gene mutations or changes on plant metabolism that cause resistance to specific or groups from a similar mode of action. There are 3 levels of herbicide resistance, namely: (i) single resistance that occurs when weeds are resistant to only one group of herbicides and or one mode of action (e.g. resistant to glyphosate), (ii) crossresistance that occurs when weeds are resistant to one or 
more herbicide groups with similar mode of action (e.g. resistant to sulfonylurea and imidazolinone herbicides, both included on Acetolactate synthase (ALS) mode of action), (iii) multiple resistance that occurs when weeds are resistant to more than two groups of herbicides and more than two modes of action herbicides (e.g. resistance to Pursuit (ALS) and glyphosate).

Control of $E$. indica with similar active ingredients of herbicide will cause the E. indica to evolve into herbicideresistant. Research on oil palm plantations in North Sumatra Province has not overall reported that E. indica was resistant to glyphosate. Lubis et al. (2012) reported that $71.70 \%$ of $E$. indica populations from Adolina Estate in the Serdang Bedagai District were resistant to glyphosate at the dose of $720 \mathrm{~g}$ a.i ha ${ }^{-1}$ and the resistance index value was 7-fold compared to the susceptible populations. Dalimunthe et al. (2015) reported that $76.67 \%$ of $E$. indica populations from Adolina Estate in the Serdang Bedagai District were resistant to glyphosate at the dose of $960 \mathrm{~g}$ a.i $\mathrm{ha}^{-1}$ and the resistance index value was 7.5-fold compared to the susceptible populations. In addition, Rahmadhani et al. (2016) also reported that $73.30 \%$ of E. indica populations from Adolina Estate in the Serdang Bedagai District were glyphosate-resistant at the dose of $960 \mathrm{~g}$ a.i $\mathrm{ha}^{-1}$ and the resistance index value were 16.7-fold compared to susceptible populations, E. indica populations from Sei Daun Estate in the South Labuhanbatu District, Sawit Seberang Estate in the Langkat District, and Rambutan Estate in the Serdang Bedagai District had also been a glyphosate-resistant of $53.30 \% ; 36.70 \%$; $33.30 \%$ and $40.00 \%$ respectively, at the dose of $480 \mathrm{~g} \mathrm{a.i} \mathrm{ha-1}$ and the resistance index values were $6.3 ; 5.1 ; 5.2$; and 5.8 -fold respectively. Syahputra et al. (2016) also reported that $E$. indica populations from the first to $9^{\text {th }}$ afdeling blocks on
Adolina Estate in the Serdang Bedagai District was glyphosate-resistance at the dose of $480 \mathrm{~g}$ a.i ha ${ }^{-1}$ amounted to $98.28 \%$, glyphosate-resistant developing of $1.72 \%$, and the glyphosate-susceptible population was absent

Previous studies had reported glyphosate resistance in E. indica only in Serdang Bedagai District but report on the glyphosate resistance of $E$. indica populations in oil palm plantations of the whole North Sumatra Province was not available at present. In 2017, North Sumatra Province had oil palm area as a government estate of 324,938 ha, private and foreign estate of 720,009 ha and smallholder of 429,951 ha (Directorate General of Estate Crops 2017). Therefore, it is a need to collect information on population distribution and to determine the glyphosate resistance of E. indica populations from oil palm plantations in North Sumatra. This research was aimed to assess the distribution of $E$. indica population and glyphosate resistance level in oil palm plantations in 11 districts in North Sumatra Province, Indonesia.

\section{MATERIALS AND METHODS}

\section{Seed collection of resistant and susceptible Eleusine indica}

A simple random sampling method was used to collect mature seeds of 50 panicles of E. indica growing between rows of oil palm from several afdeling oil palm plantations in 11 districts in North Sumatra Province (Table 1 and Figure 1) (Tampubolon and Purba 2018a). Seeds of glyphosate-susceptible $E$. indica $\left(\mathrm{ESU}_{0}\right)$ was collected at soccer field of Politeknik Negeri Medan (Medan city), where the herbicide has never been applied. Collection of $E$. indica seeds was conducted from October 2016 until February 2017.

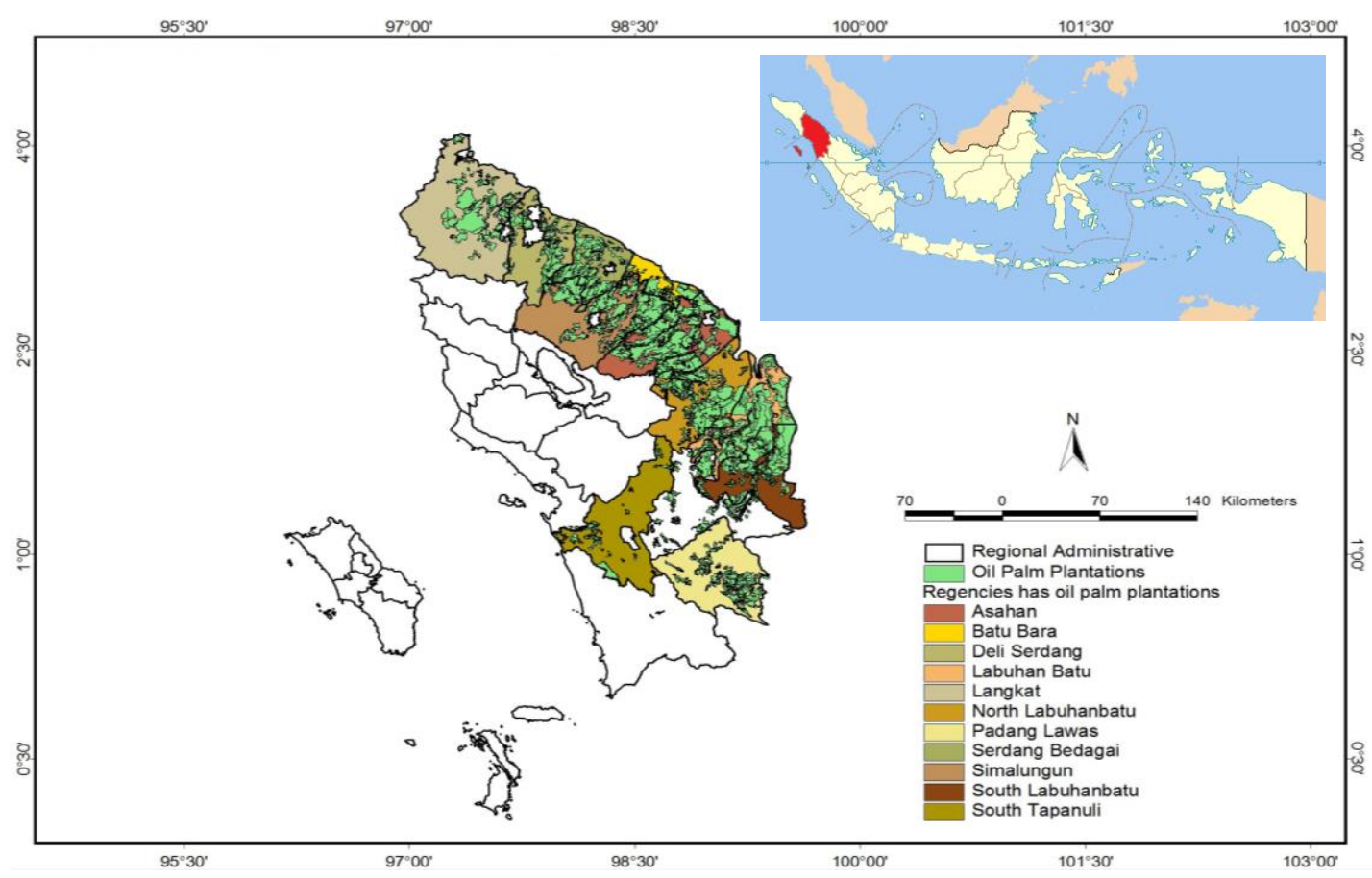

Figure 1. Map of Eleusine indica seeds collected in 11 districts in North Sumatra Province, Indonesia 
Table 1. Oil palm plantations area and the total sample of Eleusine indica populations in 11 districts in North Sumatra Province, Indonesia

\begin{tabular}{lrrr}
\hline \multicolumn{1}{c}{ Districts } & \multicolumn{2}{c}{ Area (ha)* } & \\
\cline { 2 - 3 } & \multicolumn{1}{c}{$\begin{array}{c}\text { Government } \\
\text { estate }\end{array}$} & $\begin{array}{c}\text { Private and } \\
\text { foreign } \\
\text { estates }\end{array}$ & Sample \\
\hline Langkat & 42,090 & 58,585 & 19 \\
Deli Serdang & 14,373 & 33,171 & 23 \\
Serdang Bedagai & 25,878 & 42,292 & 47 \\
Batu Bara & 2,401 & 0 & 12 \\
Asahan & 43,891 & 66,255 & 107 \\
Simalungun & 65,408 & 18,127 & 90 \\
Labuhabatu & 53,838 & 247,680 & 18 \\
North Labuhanbatu & 3,287 & 53,108 & 28 \\
South Labuhanbatu & 49,840 & 71,207 & 49 \\
Padang Lawas & 6,542 & 0 & 22 \\
South Tapanuli & 7,637 & 42,619 & 6 \\
& \multicolumn{3}{c}{ Total } \\
\hline Note : *Directorate General of Estate Crops (2017)
\end{tabular}

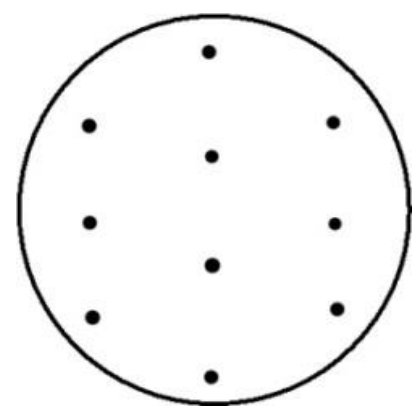

Figure 2. Illustration of planting pot containing 10 Eleusine indica seedlings. The black dot represents the position of the seedling in the pot.

\section{Germination and transplanting}

E. indica seeds were soaked in $0.2 \% \mathrm{KNO}_{3}$ for $30 \mathrm{~min}$ (Ismail et al. 2002) which aimed to break the dormancy of $E$. indica seeds. Topsoil and manure were mixed with the $1: 1$ volume ratio for germination media put in pots. The media was sterilized using an autoclaved at $100^{\circ} \mathrm{C}$ temperature for 3 hours (Tampubolon and Purba 2018a) and was then filled into the germination trays of $33 \mathrm{~cm} \times 24$ $\mathrm{cm}$ size. Insecticide was sprayed at 3 days after germinated to prevent it from red imported fire ant (Solenopsis invicta) attack. Seedlings of $E$. indica were transplanted into pots of $13.5 \mathrm{~cm} \times 10.5 \mathrm{~cm}$ size filled with the media composed of mixture of topsoil, sand, and manure (1: 1: 1 volume ratio). Each pot was planted with ten seedlings of $E$. indica (Figure 2). The seedling preparation and transplantation were conducted in the Weed Research Center Field Laboratory, the Faculty of Agriculture, the Universitas Sumatera Utara.

\section{Glyphosate application}

Eleusine indica seeds from different locations were planted in pots arranged in non-factorial Randomized
Block Design (RBD) with three replications. Glyphosate herbicide was sprayed at the recommended dose of $720 \mathrm{~g}$ a.i ha ${ }^{-1}$. The glyphosate spraying was conducted when the E. indica was at 3-4 leaf stage (Hess et al. 1997). The spray volume was calibrated at $2921 \mathrm{ha}^{-1}$. Spraying was conducted during sunny weather $\left(29^{\circ} \mathrm{C}\right.$ temperature and $74 \%$ moisture).

\section{Data analysis}

The parameters observed in this research included mortality, resistance level, and dry weight of $E$. indica. The observation was done at 21 days after spraying (DAS) (Jalaludin et al. 2015). The dry weight of E. indica was collected at six weeks after spraying (WAS) after oven dried at $80^{\circ} \mathrm{C}$ for 48 hours (SERAS 1994). The mortality data were analyzed using one-way ANOVA, and the means were separated using Duncan Multiple Range post hoc Test at $5 \%$ significance level. The statistical analysis was performed using an IBM SPSS Statistics v.20 software. The percentage of mortality was calculated using the following formula:

$$
\text { Mortality of E. indica }=\frac{\sum \text { E.indica was died }}{\sum E \text {.indica } \text { was planted }} \times 100 \%
$$

The resistance level of $E$. indica was determined based on the percentage of mortality caused by glyphosate spray. E. indica with percent mortality of $>98-100 \%$ was classified as glyphosate-susceptible (S), >80-98\% was classified as glyphosate-resistant developing (DR), and $\leq 80 \%$ was classified as glyphosate-resistant (R) (Owen and Powles 2009).

\section{RESULTS AND DISCUSSION}

Eleusine indica mortality collected from oil palm plantations on 11 districts in the North Sumatra were dominantly resistant to the recommended glyphosate dose of $720 \mathrm{~g} \mathrm{a.i} \mathrm{ha}^{-1}$ (Figure 3). Glyphosate at recommended dose of $720 \mathrm{~g}$ a.i ha ${ }^{-1}$ was significantly effective to control E. indica from oil palm plantations in Langkat District (11 populations), Deli Serdang District (7 populations), Asahan District (16 populations), Simalungun District (18 populations), North Labuhanbatu District (7 populations), South Labuhanbatu District (3 populations), Padang Lawas District (8 populations), and South Tapanuli District (one population), however the herbicide was less effective in the Serdang Bedagai, Batu Bara, and Labuhan Batu Districts (showed by notation in Figure 3). E. indica populations have become glyphosate-resistant due to frequent use of glyphosate at recommended dose of $720 \mathrm{~g}$ a.i ha ${ }^{-1}$ in oil palm plantations in the North Sumatra. This is in line with the finding that glyphosate-susceptible E. indica ranged from 0 to $27.27 \%$ (Table 2). Chen et al. (2015) found that the mortality of 12 biotypes E. indica in the Chengdu and Guangzhou, China was classified as low level (less than $100 \%$ ) at 14 days after glyphosate spray at the dose of $1,680 \mathrm{~g}$ a.i ha ${ }^{-1}$ whereas 12 biotypes had been sprayed using glyphosate more than 3 times a year at the dose $840 \mathrm{~g}$ a.i 
ha $^{-1}$. Besides, Simarmata et al. (2005) also reported a $41 \%$ mortality of $\mathrm{F}_{1}$ Rigid ryegrass from California at the glyphosate dose of $2.24 \mathrm{~kg} \mathrm{ha}^{-1}$ ( $2 \mathrm{x}$ recommended dosage).

The results showed that more than $50 \%$ populations of $E$. indica collected from oil palm plantations in 11 districts were resistant to glyphosate applied at the recommended dose of $720 \mathrm{~g}$ a.i ha ${ }^{-1}$ (Table 2). Four hundred twenty-one populations of $E$. indica collected from North Sumatra (Table 1), the glyphosate-susceptible populations ranged from 0.00 to $27.27 \%$, glyphosate-resistant developing ranged from 8.16 to $42.11 \%$, and glyphosate-resistant ranged from 36.36 to $89.36 \%$. E. indica populations that were classified as glyphosate-resistant were from eight of 11 districts in North Sumatra. The highest percentage of resistant populations was found in Serdang Bedagai District of $89.36 \%$ (Table 2), which presumably caused by the excessive use of glyphosate herbicide to control $E$. indica in oil palm plantations at a dose of $720 \mathrm{~g}$ a.i ha ${ }^{-1}$ not only in nursery but also in immature and mature of oil palm plants. The increased number of glyphosate-resistant $E$. indica populations resulted in the failure of weed control in oil palm plantations. This failure do occur because the glyphosate inhibits the 5-enolpyruvylshikimate-3phosphate synthase (EPSPS) enzyme the in plant chloroplasts tissue, which then resulted in the accumulation of shikimic acid. This is consistent to Molin et al. (2013) who stated that increased shikimic acid levels in $E$. indica leaf exposed to glyphosate indicated an increase in resistance level of 5 to 8 -fold compared to susceptible populations from Washington County, Mississippi. Zhang et al. (2015) stated that the EPSPS enzyme in glyphosateresistant E. indica biotypes from South China quickly responded to glyphosate herbicide at 12 hours after exposure. The mRNA and protein expression of glyphosate-resistant $E$. indica biotypes constantly increases with increasing glyphosate concentration. Chen et al. (2015) also stated that glyphosate-resistant E. indica biotype has a small decrease in chlorophyll content at the glyphosate dose of $1,680 \mathrm{~g}$ a.i ha ${ }^{-1}$.
The dry weight ranges of glyphosate-resistant $E$. indica collected in oil palm plantations in 11 districts in North Sumatra can be seen in Figure 4.

The dry weight ranges of glyphosate-resistant $E$. indica populations were found in 5 districts included South Labuhanbatu District followed by Serdang Bedagai District, Simalungun District, Asahan District, and North Labuhanbatu District. The increased in dry weight ranges indicated that $E$. indica can produce higher biomass, which then followed by the production of seeds of the resistant $E$. indica populations and, thus, influence their distribution. The high biomass production did occur because the active ingredient of glyphosate was unable to inhibit amino acid synthesis for protein formation in glyphosate-resistant $E$. indica populations. The observed glyphosate-resistant $E$. indica populations in 5 districts are highly alarming and a beneficial information for oil palm plantation companies to prevent increased cost for weed control. According to Widayat and Yustisiyanika (2015), glyphosate potassium herbicide at the dose of $330 \mathrm{~g}$ a.i ha ${ }^{-1}\left(1.51 \mathrm{ha}^{-1}\right), 660 \mathrm{~g}$ a.i

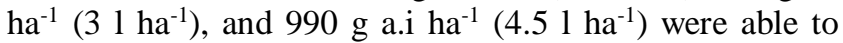
suppress the grasses dry weight at 6 weeks after planting (WAP) in soybean cultivation up to $2.80 \mathrm{~g} ; 2.89 \mathrm{~g}$; and $2.76 \mathrm{~g}$ respectively. In addition, Dalimunthe et al. (2015) also stated that glyphosate-resistant $E$. indica biotypes dry weight from Adolina Estate were $7.00 \mathrm{~g} \mathrm{pot}^{-1}$ with glyphosate application at the dose of $480 \mathrm{~g}^{\mathrm{a} . \mathrm{i} \mathrm{ha}} \mathrm{ha}^{-1}$, while the dry weight was decreased to 5.37 and $0 \mathrm{~g} \mathrm{pot}^{-1}$ if the dose applied was at 960 and $1,920 \mathrm{~g}^{\mathrm{a} . \mathrm{i} \mathrm{ha}} \mathrm{ha}^{-1}$, respectively.

The resistance level of E. indica at oil palm plantations in 11 districts in North Sumatra can be seen in Figure 5. 276 E. indica populations $(65.56 \%)$ were classified as glyphosate-resistant, 88 populations (20.90\%) were classified as glyphosate-resistant developing and 57 populations (13.54\%) were classified as glyphosatesusceptible.

Table 2. The resistance level of Eleusine indica from oil palm plantations in 11 districts in North Sumatra at 21 days after spraying (DAS).

\begin{tabular}{|c|c|c|c|}
\hline \multirow{2}{*}{ Districts } & \multicolumn{3}{|c|}{ Resistance level of Eleusine indica populations } \\
\hline & $\mathbf{S}$ & DR & $\mathbf{R}$ \\
\hline Langkat ${ }^{\mathrm{a}}$ & 3 pop. $(15.79 \%)$ & 8 pop. $(42.11 \%)$ & 8 pop. $(42.11 \%)$ \\
\hline Deli Serdang ${ }^{b}$ & 3 pop. $(13.04 \%)$ & 7 pop. $(30.43 \%)$ & 13 pop. $(56.52 \%)$ \\
\hline Serdang Bedagai ${ }^{c}$ & 0 pop. $(0.00 \%)$ & 5 pop. $(10.64 \%)$ & 42 pop. $(89.36 \%)$ \\
\hline Batu Bara ${ }^{e}$ & 0 pop. $(0.00 \%)$ & 2 pop. $(16.67 \%)$ & 10 pop. $(83.33 \%)$ \\
\hline Asahan & 17 pop. $(15.89 \%)$ & 21 pop. $(19.63 \%)$ & 69 pop. $(64.49 \%)$ \\
\hline Simalungun & 18 pop. $(20.00 \%)$ & 19 pop. $(21.11 \%)$ & 53 pop. $(58.89 \%)$ \\
\hline Labuhanbatu & 0 pop. $(0.00 \%)$ & 5 pop. $(27.78 \%)$ & 13 pop. (72.22\%) \\
\hline North Labuhanbatu & 7 pop. $(25.00 \%)$ & 8 pop. $(28.57 \%)$ & 13 pop. (46.43\%) \\
\hline South Labuhanbatu & 3 pop. $(6.12 \%)$ & 4 pop. $(8.16 \%)$ & 42 pop. $(85.71 \%)$ \\
\hline Padang Lawas ${ }^{\mathrm{d}}$ & 6 pop. $(27.27 \%)$ & 8 pop. $(36.36 \%)$ & 8 pop. $(36.36 \%)$ \\
\hline South Tapanuli ${ }^{\mathrm{d}}$ & 0 pop. $(0.00 \%)$ & 1 pop. $(16.67 \%)$ & 5 pop. $(83.33 \%)$ \\
\hline
\end{tabular}

Note : *S: susceptible (E. indica mortality > 98-100\%); DR: resistant developing (E. indica mortality > 80-98\%); R: resistant (E. indica mortality $\leq 80 \%$ ) (Owen and Powles 2009); pop.: populations. a (Tampubolon and Purba 2018b); b (Tampubolon et al. 2018a); c (Tampubolon et al. 2018b); d (Tampubolon and Purba 2018a); e (Tampubolon et al. 2018c). 
A

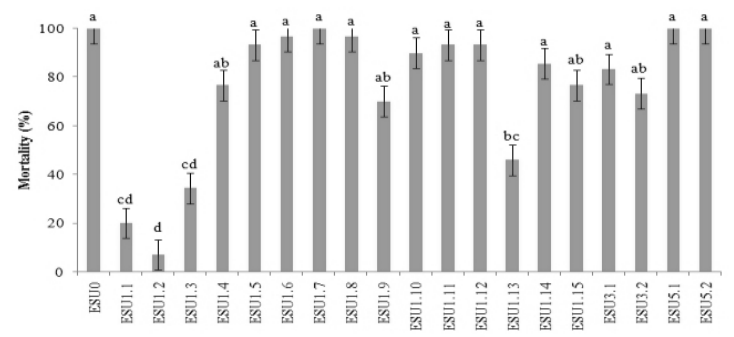

C
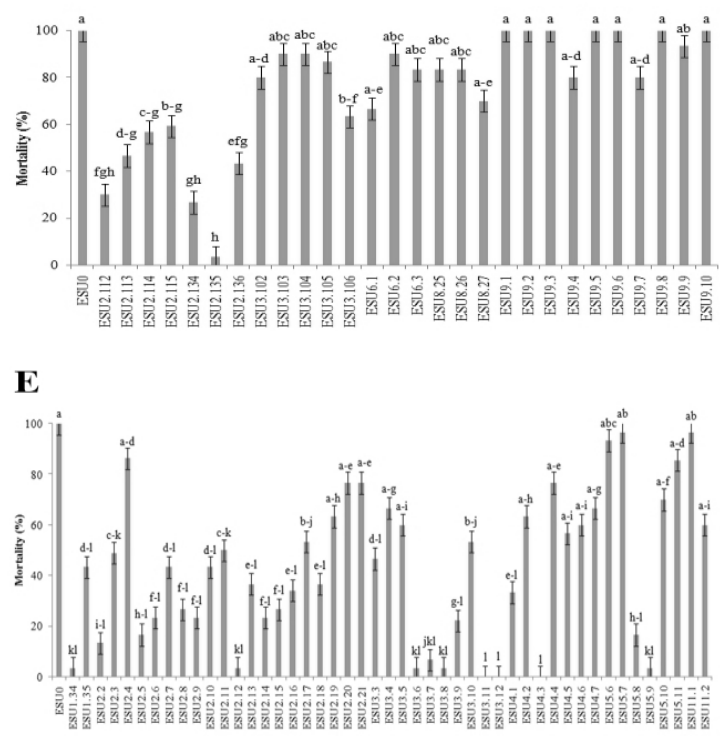

B

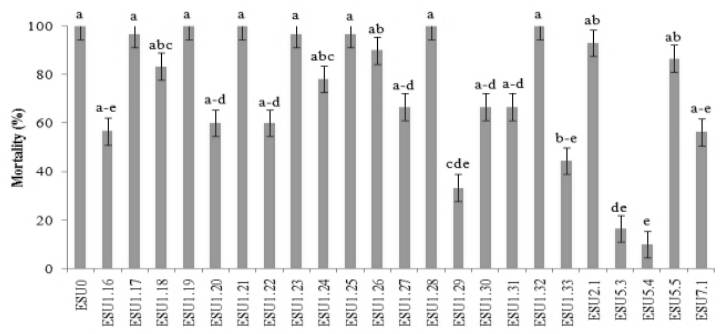

D

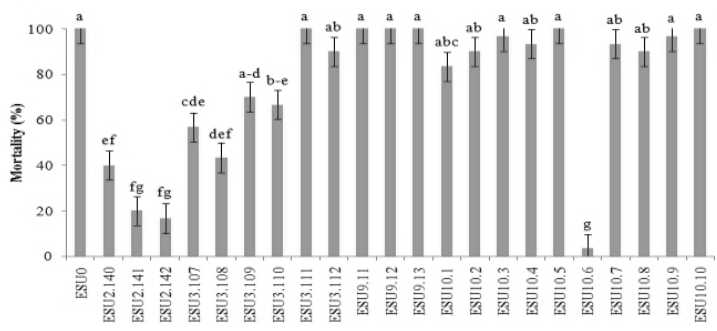

$\mathbf{F}$

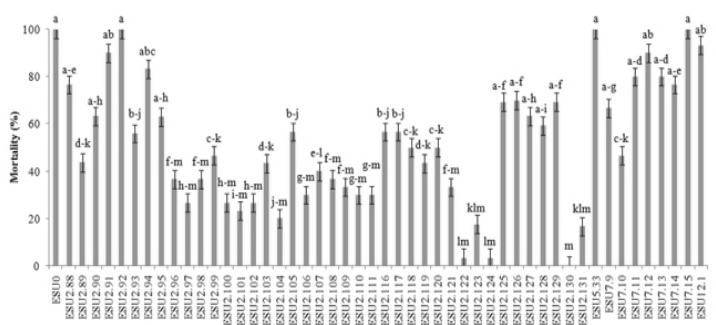

G

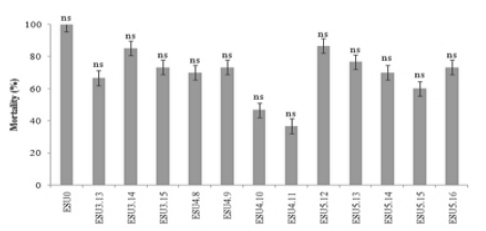

$\mathbf{H}$

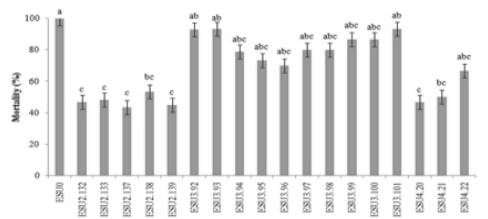

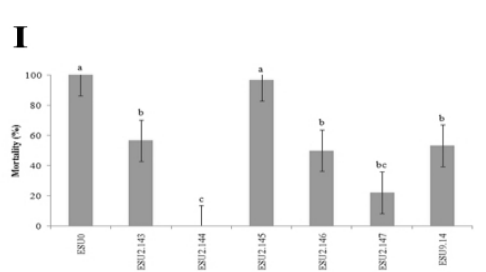

$\mathbf{J}$

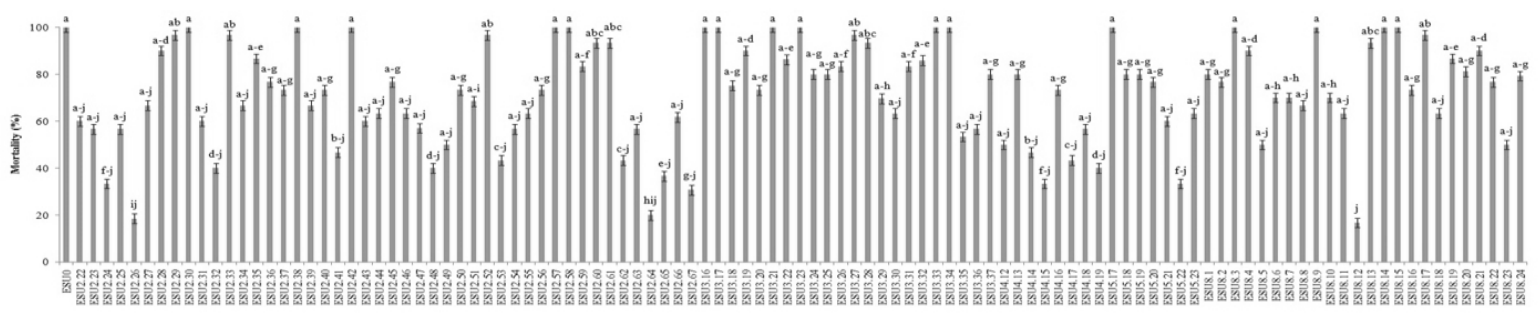

$\mathbf{K}$

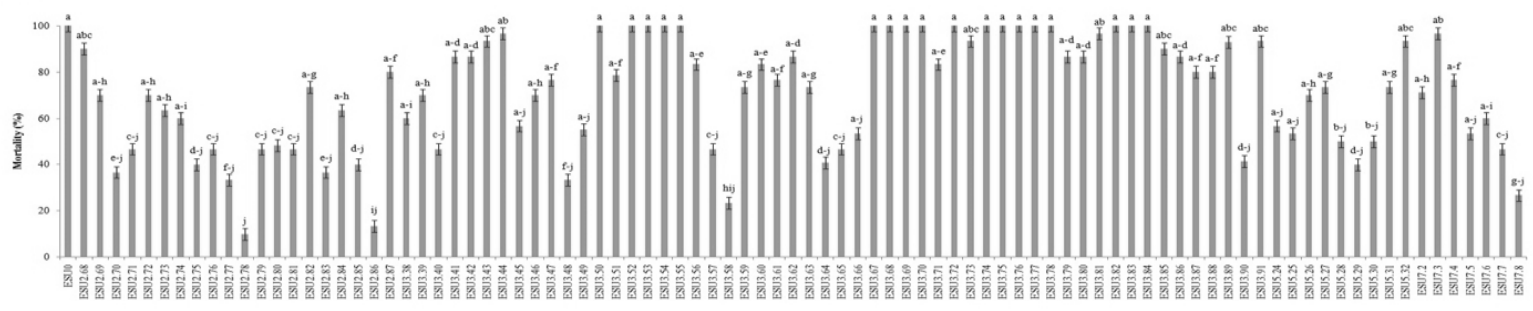

Figure 3. Graphs showing the glyphosate-induced mortality of Eleusine indica collected in oil palm plantations in 11 districts in North Sumatra, Indonesia. A. Langkat, B. Deli Serdang, C. North Labuhanbatu, D. Padang Lawas, E. Serdang Bedagai, F. South Labuhanbatu, G. Batu Bara, H. Labuhan Batu, I. South Tapanuli, J. Asahan, K. Simalungun. Vertical bars indicate \pm SE. Bars having the same lowercase are not significantly different at 5\% DMRT. 


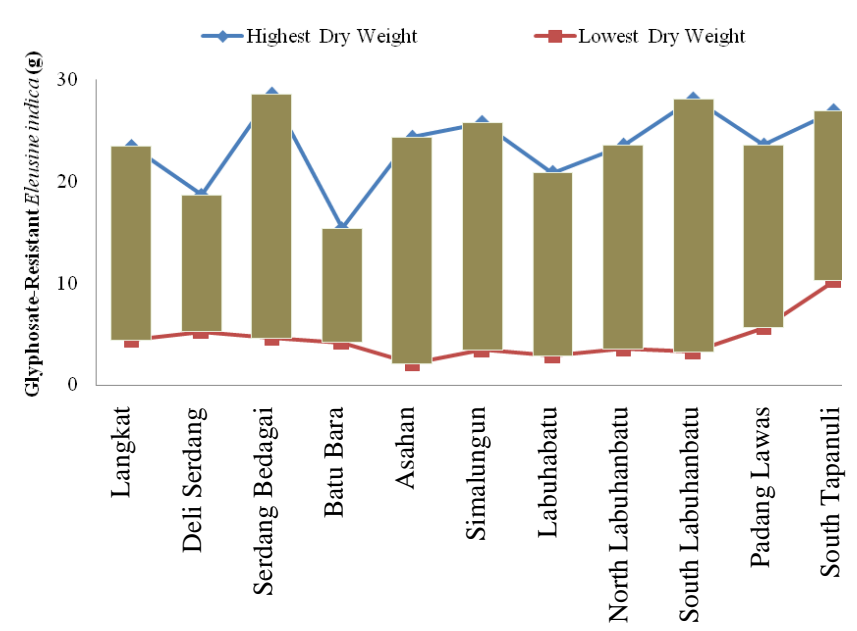

Figure 4. The dry weight ranges of glyphosate-resistant Eleusine indica were collected from oil palm plantations in 11 districts in North Sumatra.

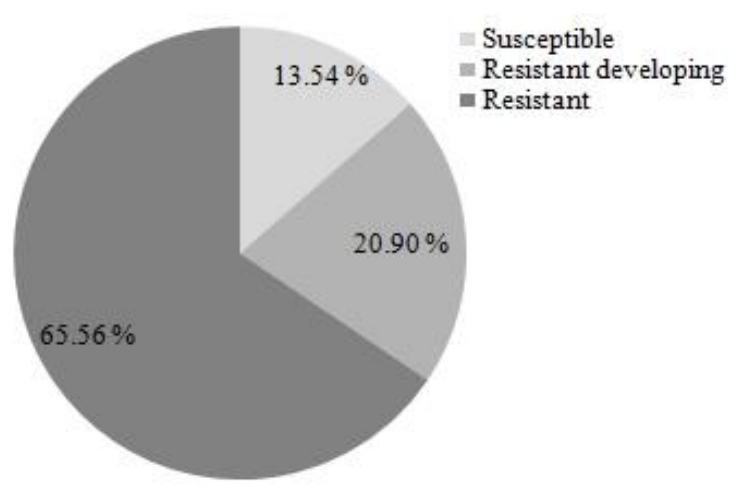

Figure 5. The resistance level of Eleusine indica from oil palm plantations in 11 districts in North Sumatra at 3 weeks after spraying.

Information on the observed glyphosate-resistant $E$. indica populations illustrates the difficulty of oil palm plantations holders to control E. indica. The higher the percentage of glyphosate-resistant $E$. indica population, the more difficult the control of this weed. The resistant $E$. indica populations are very disturbing for oil palm plants in producing fresh fruit bunches (FFB) both in quality and quantity. These populations, under oil palm plantations, will produce more tillers making them stronger in competing with oil palm plants to obtain nutrients and water, which in turn inhibit the growth and development of oil palms, primarily the immature plant. The evidence of glyphosate-resistant $E$. indica on oil palm plantations in North Sumatra had been reported by previous research. Tampubolon and Purba (2018a) reported that $36.36 \%$ and $83.33 \%$ of E. indica from Padang Lawas and Tapanuli Selatan District were resistant to glyphosate at the dose of $720 \mathrm{~g}$ a.i ha ${ }^{-1}$. Tampubolon and Purba $(2018 \mathrm{~b})$ reported that $42.11 \%$ of $E$. indica in Langkat District were glyphosate resistance at the dose of $720 \mathrm{~g}$ a.i ha ${ }^{-1}$. Syahputra et al.
(2016) reported that $98.28 \%$ of E. indica from Adolina Estate in the Serdang Bedagai District were glyphosateresistant at the dose of $480 \mathrm{~g}$ a.i ha ${ }^{-1}$. Tampubolon et al. (2018a) reported that $56.62 \%$ of E. indica in the Deli Serdang District were glyphosate-resistant at the dose of $720 \mathrm{~g}$ a.i ha ${ }^{-1}$. Tampubolon et al. (2018b) reported that $89.36 \%$ of E. indica in the Serdang Bedagai District was glyphosate-resistant at the dose of $720 \mathrm{~g}$ a.i ha-1. Tampubolon et al. (2018c) also reported that $83.33 \%$ of $E$. indica in the Batu Bara District were glyphosate-resistant at the dose of $720 \mathrm{~g}$ a.i ha ${ }^{-1}$. Survey of glyphosate-resistant $E$. indica from oil palm plantations are urgently needed as initial information in making decisions weed control in the case of the spread of resistant biotypes. This decision will benefit the company in saving weed control costs for the top management in purchasing herbicides that are appropriate to the resistance level.

In conclusions, $E$. indica populations collected in oil palm plantations in 11 districts in North Sumatra Province were classified as glyphosate-resistant, glyphosate-resistant developing, and glyphosate-susceptible of $65.56 \%$ (276 populations), $20.90 \%$ (88 populations), and $13.54 \%$ (57 populations), respectively based on the recommended glyphosate dose of $720 \mathrm{~g}$ a.i ha ${ }^{-1}$. The highest ranges of dry weight of glyphosate-resistant $E$. indica populations were found in 5 districts including South Labuhanbatu District followed by Serdang Bedagai, Simalungun, Asahan, and North Labuhanbatu Districts.

\section{ACKNOWLEDGMENTS}

The authors would like to thank the Ministry of Research, Technology \& Higher Education of the Republic of Indonesia for funding this research through Program Magister menuju Doktor Sarjana Unggul (PMDSU) research scheme and also the Faculty of Agriculture, Universitas Sumatera Utara and oil palm plantations in North Sumatra for supporting the field experiment.

\section{REFERENCES}

Ampong-Nyarko K, De Datta SK, Dingkuhn M. 1992. Physiological response of rice and weeds to low light intensity at different growth stages. Weed Res 32 (6): 465-472. DOI: 10.1111/j.13653180.1992.tb01907.x.

Chen JC, Huang HJ, Wei SH, Zhang CX, Huang ZF. 2015. Characterization of glyphosate-resistant goosegrass (Eleusine indica) populations in China. J Integr Agric 14 (5): 919-925. DOI: 10.1016/S2095-3119(14)60910-2.

Chin HF. 1979. Weed seed-A potential source of danger. Proceedings of the Plant Protection Seminar. 22-23 September 1979.

Dalimunthe SP, Purba E, Meiriani. 2015. Dose response of glyphosateresistant goosegrass (Eleusine indica L. Gaertn) biotype to Glyphosate, Paraquat, and Indaziflam. J Online Agroekoteknologi 3 (2): 625-633. [Indonesian]

Directorate General of Estate Crops. 2017. Tree crop estate statistics of Indonesia 2015-2017. Ministry of Agriculture, Jakarta, Indonesia. [Indonesian]

Ganeshaiah KN, Umashaanker R. 1982. Evolution of Reproductive Behavior in the Genus Eleusine. Euphytica 31 (2): 397-404. 
Hess M, Barraljs G, Bleiholder H, Buhr L, Eggers T, Hack H, Stauss R. 1997. Use of the extended BBCH Scale - General for the descriptions of the growth stages of mono and dicotyledonous weed species. Weed Res 37 (6): 433-441. DOI: 10.1046/j.1365-3180.1997.d01-70.x.

Ismail BS, Chuah TS, Salmijah S, Teng YT, Schumacher RW. 2002. Germination and seedling emergence of glyphosate-resistant and susceptible biotypes of goosegrass (Eleusine indica [L.] Gaertn.). Weed Biol Manag 2 (4): 177-185. DOI: 10.1046/j.14456664.2002.00066.X.

Jalaludin A, Yu Q, Powles SB. 2015. Multiple resistance across Glufosinate, Glyphosate, Paraquat and ACCase-inhibiting herbicides in an Eleusine indica population. Weed Res 55 (1): 82-89. DOI: 10.1111/wre. 12118 .

Knezevic SZ, Jhala A, Gaines T. 2017. Herbicide Resistance and Molecular Aspects. $2^{\text {nd }}$ ed. Encyclopedia of Applied. Plant Sci 3: $455-$ 458. DOI: 10.1016/B978-0-12-394807-6.00025-3.

Lubis LA, Purba E, Sipayung R. 2012. Dose response of glyphosateresistant Eleusine indica biotype to Glyphosate, Paraquat, and Glufosinate. J Online Agroekoteknologi 1 (1): 109-123. [Indonesian]

Molin W, Wright A, Nandula V. 2013. Glyphosate-resistant Goosegrass from Mississippi. Agronomy 3 (2): 474-487. DOI: 10.3390/agronomy3020474.

Monaco JT, Weller CS, Ashton MF. 2002. Weed Science Principles and Practices. $4^{\text {th }}$ ed. John Wiley \& Sons. Inc, New York.

Mysore KS, Baird V. 1997. Nuclear DNA content in species of Eleusine (Gramineae): a critical re-evaluation using laser flow cytometry. Plant Syst Evol 207 (1-2): 1-11. DOI: 10.1007/BF00985206.

Owen MJ, Powles SB. 2009. Distribution and frequency of herbicideresistant wild oat (Avena spp.) across the Western Australian Grain Belt. Crop Pasture Sci 60 (1): 25-31. DOI: 10.1071/CP08178.

Purba E. 2009. Keanekaragaman Herbisida dalam Pengendalian Gulma Mengatasi Populasi Gulma Resisten dan Toleran Herbisida. Pidato Pengukuhan Jabatan Guru Besar Tetap Universitas Sumatera Utara. Medan. [Indonesian]

Rahmadhani A, Purba E, Hanafiah DS. 2016. Response of five populations herbicide resistant Eleusine indica L. Gaertn to Glyphosate and Paraquat. J Online Agroekoteknologi 4 (4): 22452254. [Indonesian]
SERAS. 1994. Standard operating procedures:plant biomass determination. Sci Eng Response Anal Serv 1-5 p. DOI: 10.1201/b14412-17.

Simarmata M, Bughrara S, Penner D. 2005. Inheritance of glyphosate resistance in rigid ryegrass (Lolium rigidum) from California. Weed Sci 53(5): 615-619. DOI: 10.1614/WS-04-187R.1.

Syahputra AB, Purba E, Hasanah Y. 2016. Distribution of herbicide multipple resistant Eleusine indica L. Gaertn. an Oil Palm Estate in North Sumatra. J Online Agroekoteknologi 4 (4): 2407-2419. [Indonesian]

Tampubolon K, Purba E. 2018a. Screening single resistance of Eleusine indica on oil palm plantation in Padang Lawas and Tapanuli Selatan District Indonesia. J Natural 18 (2): 101-106. DOI: 10.24815/jn.v18i2.11223. [Indonesian]

Tampubolon K, Purba E. 2018b. Resistance confirmation of Eleusine indica to Glyphosate on oil palm plantations in Langkat District. J Pertanian Tropik 5 (2): 276-283. [Indonesian]

Tampubolon K, Purba E, Hanafiah DS, Basyuni M. 2018a. Population distribution and resistance classification of Eleusine indica to Glyphosate on oil palm plantations in Deli Serdang District. Caraka Tani: J Sustain Agric 33 (2): 146-152. DOI: 10.20961/carakatani.v33i2.24300. [Indonesian]

Tampubolon K, Purba E, Basyuni M, Hanafiah DS. 2018b. Distribution mapping of glyphosate-resistant Eleusine indica in Serdang Bedagai District. J Natural 18 (3): 127-134. DOI: 10.24815/jn.v0i0.11201. [Indonesian]

Tampubolon K, Purba E, Hanafiah DS. 2018c. Resistance of Eleusine indica to Glyphosate on oil palm plantations in Batu Bara District. J Agrotek Tropika 6 (3): 133-39. doi:DOI: 10.23960/jat.v6i3.2798. [Indonesian]

Widayat D, Yustisiyanika RG. 2015. Effect of glyphosate herbicides dose on weeds growth and yield of three cultivars of soybean in no tillage system. J Kultivasi 14 (2): 23-28. DOI: 10.24198/kltv.v14i2.12070. [Indonesian]

Zhang C, Feng L, He TT, Yang CH, Chen GQ, Tian XS. 2015. Investigating the mechanisms of Glyphosate resistance in goosegrass (Eleusine indica) population from South China. J Integr Agric 14 (5): 909-918. DOI: 10.1016/S2095-3119(14)60890-X. 